\title{
On Editing the 70th Anniversary Special Issue " Progress of \\ the Iron and Steel Technologies in Japan in the Past Decade"
}

\author{
By Ohmi MIYAGAWA*
}

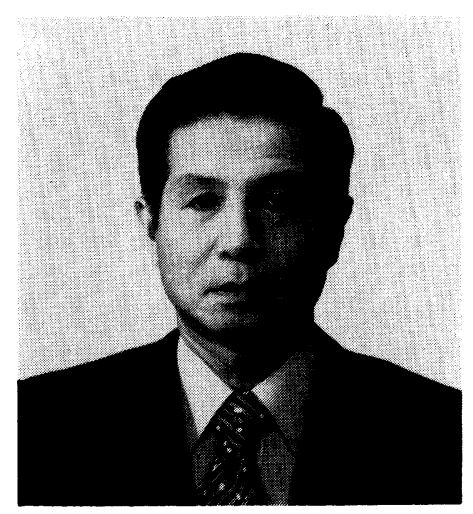

As a part of commemoration of the 70th anniversary of founding of the Iron and Steel Institute of Japan (ISIJ), it has been decided to publish a special issue of the Tetsu-to-Hagané and the Transactions ISIJ, under a title of the "Progress of the Iron and Steel Technologies in Japan in the Past Decade". Accordingly, the Editorial Gommittee of the ISIJ has established within itself the Special Editorial Committee for Publication of the 70th Anniversary Special Issue, and entrusted it with all the pertinent works.

Thereupon, the Special Editorial Committee, whose chairman I was appointed to, had organized Expertise Subcommittees for the sectors of the ironmaking, the steelmaking, the shaping and fabrication. instrumentation and control, and the products, traditional and new, with members of the Special Editorial Committee serving either as the chairman or as the secretary. Thus, the editing work was undertaken by those subcommittees, also soliciting and incorporating opinions from the Joint Research Society and other research organizations of the ISIJ as much as possible.

Now, the ISIJ had, if to be limited to the post-war period, published the special issues on the occasions of the 40th, 50th and 60th anniversaries, respectively in Showa 30 (1955), 40 (1965) and 50 (1975), each issue gaining favorable reception. Therefore, on the basis of these prideful accomplishment, we have set the basic policy of editing the present 70th Anniversary Special Issue to be a "comprehensive review of the progress achieved in Japan during the past decade in sciences and technologies of iron and steel, thereby elucidating their current standing with regard to the world-wide development ".

In retrospect, however, the period encompassing

the Showa 30's and 40's (1955 to 1974), namely the time when the previous three special issues were planned and published, had been a time of great expansion for our iron and steel industry as well as for Japanese economy, whereas the period after the first Oil Crisis that broke out in the fall of Showa 48 (1973), namely the very period that the present special issue intends to cover, has been the time of general economic stagnation under which the Japanese iron and steel industry had to strive for freedom from the total reliance on imported petroleum, for saving of energy in general, and for improvement of products yield to enhance what little profit there was. Further, those severe demands for rationalization had also instigated the rapid progress of the instrumentation and control technologies by making full uses of electronics and system engineering methodologies, which is another feature of this period.

More recently, however, in the midst of the worldwide decline of demand for steel products, further refinement of each technology and further upgrading of every product are being called for all the more urgently on one hand, and interests in new materials of a high added value are mounting with increasing intensity on the other. The changes that had occurred in the iron and steel technologies through the past decade in correspondence to the changing needs of the modern age had not only been truly dazzling, but thus been something that did not know precedents, a fact that makes the present editing work rather unique.

With those as a background, we have designed to open the Special Issue with a General Overview, in which the changes in the energy structure of Japan of the past decade and the corresponding evolution of iron and steel technologies are comprehensively reviewed. This is followed by the chapter of Shaping and Fabrication.Instrumentation and Control, in which along with the progress achieved by metal working and treating technologies, the advances made by the instrumentation and control technologies in the fields of ironmaking and raw materials, steelmaking, rolling of steels, and pipemaking are integrally discussed. Further, in the chapter of Products, Traditional and New, those some ten different topics of new materials, such as the ultra-fine particles, rapidly cooled thin ribbons, amorphous metals and titanium alloys are examined together with the more traditional, but markedly improved, materials.

As for the guidelines for the individual writers,

* Chairman, The Special Editorial Committee for Publication of the 70th Anniversary Special Issue; Professor, Faculty of Technology, Tokyo Metropolitan University. 
three principles have been set forth. Those are:

(1) that every description should be made in reference to the Overview of that Chapter;

(2) that themes should be chosen on a preference basis from those technologies and products that have made an exceptional progress since the time of publication of the 60th Anniversary Issue (Tetsu-to-Hagané, March 1975; Japanese version only), and not only their technical features but the situations in which they were given an inducement for development and their future prospects as well should be described; and

(3) that development of a theme should be done not in a flat item-by-item description manner, but in a highlighting way.

And, to aid in the writing, it was agreed that no references, except when quoting an original table or figure off a publication other than ISIJ's, were to be cited.
When assigning the themes to the writers, we held a number of writers' meetings, by which we endeavored to convey what the Special Editorial Committee intended to each writer, while harmonizing as a whole and forestalling omissions and duplications. Whereupon, opinions were expressed to the effect that certain amount of duplication should be tolerated, for such duplication would help to bring up points of dispute in bas-relief. They were well heard and points so taken in actual editing.

Finally, on behalf of the Special Editorial Committee for Publication of the 70th Anniversary Special Issue, I should like to thank formally all the writers, editorial staffs of the ISIJ, and all those other people who worked for or with us, for their time and efforts. Also, I would like to express my gratitude for the President and Executive Board Members of ISIJ for their support. 